\title{
THE APPLICATION OF MONETARY INCENTIVE POLICY IN CURRENT ECONOMIC CONDITIONS
}

\author{
Iryna Kreidych ${ }^{1}$, Nadezhda Roshchyna², Oksana Kazak ${ }^{3}$
}

\begin{abstract}
The aim of the article is studying the process of implementation of promotional monetary policy by investigation of the functionality of the transmission mechanism channels. The paper singles out the peculiarities of the implementation of monetary policy in well-developed and developing countries. The subject of the study is: the structure of the monetary transmission mechanism; the functionalities of both traditional and non-traditional channels and their influence on promotional monetary policy are defined. An analysis of the existing structure of the transmission mechanism made it possible to determine the strength and speed of feedback between participants and the degree of influence on the real sector and to formulate appropriate proposals for its adjustment or activation. In addition, it is indicated that, under the present conditions, it is non-traditional channels that acquire special significance; also, the main factors that have shifted the priority vector in their direction are defined. Alongside this, the study presents modern modifications of promotional monetary policy and their significance for the modern economic world. Methodology. The classic methods of scientific research are used in the article, among which are the following: observation, abstraction, comparison, systematic approach, analysis, and synthesis. Results. The conducted study clearly demonstrates that, in the process of changing financial relations, the significance of the transmission mechanism channels in the process of implementing promotional monetary policy changed, too. At the same time, it is expedient to single out the reasons that lead to a change in the role of some channels of monetary transmission in relation to others. Current research and developments are not limited to the above structure of the transmission mechanism channels. Moreover, their list is constantly replenished, which is indicative of the existence of transformational processes affecting the financial sector. The approaches to the structure of the transmission mechanism and the functionality of its channels, determined in this article, make it possible to assess the effectiveness of implementing monetary policy. Practical implications. Clarified complex causes of destructive nature, which initially level out practically any actions with regard to the system approach, namely, the absence of the integrated combination of interests of all social and economic spheres: state-business-society. Also, the results of the study provide an opportunity to identify further trends in the changing transmission mechanism channels in the implementation process of monetary policy and use this knowledge by planning and forecasting for the functionality of transmission channels. Value/originality. This research was carried out within the framework of the scientific work of the Department of Theoretical and Applied Economics of the National Technical University of Ukraine "Igor Sikorsky Kyiv Polytechnic Institute" (No. 0112U007817) on the topic: "Globalization of industrial capacity formation trends in the terms of post-industrial transformation".
\end{abstract}

Key words: promotional monetary policy, channels of monetary transmission mechanism, structure of monetary transmission mechanism.

JEL Classification: B50, E50

\section{Introduction}

Modern transformations of the world economy, which form the strategic foundations of its future development, lead to a revision of the system of established values and views: from the role of the state, social institutions, political elites, the financial market to a change in the structure of economic development factors.

The pluralism of approaches when choosing a rational strategy for monetary policy and making specific managerial decisions is felt particularly deeply

\footnotetext{
Corresponding author:

${ }^{1}$ National Technical University of Ukraine “Igor Sikorsky Kyiv Polytechnic Institute”, Ukraine.

E-mail: kreidichin@gmail.com

${ }^{2}$ National Technical University of Ukraine "Igor Sikorsky Kyiv Polytechnic Institute”, Ukraine.

E-mail: 2203883@ukr.net

${ }^{3}$ Borys Grinchenko Kyiv University, Ukraine.

E-mail: kazakoksana1974@gmail.com
} 
today since unique features of the formation and development of states are reflected in the process of the above-mentioned choice. At the same time, in the transformation processes, the dominant role is played by the speed of change of ideological institutions, the historical development of which differs significantly from state to state, which further enhances the adaptive lag and, accordingly, the management process becomes more complex and requires a regular review of the fundamental foundations of one or another society. In the context of collisions of globalization processes, with simultaneous localization of economies, confrontation of political systems and meta-goals, the only way to increase the effectiveness of monetary policy is the application of a systematic approach that covers all aspects of development in a comprehensive manner.

Modern world trends show that promotional monetary policy becomes the most relevant, which is associated with some negative medium-term trends that determine the widespread slow growth of the economy.

Not only potential economic growth in well-developed and developing countries fall due to a reduction in capital expenditure, but also actual economic growth is anaemic and below its potential dynamics, which is caused by the continuation of the painful process of reducing the debt burden, first in the US, then in Europe, and now in highly debt-laden developing countries.

In this situation, numerous technological innovations did not lead to increased productivity, the progress of structural reforms remains slow, and the prolonged cyclical stagnation dilutes the basis of both professional skills and industrial capital. In addition, economic policy, especially monetary policy, is becoming less traditional; non-traditional instruments of monetary policy have become the norm in most well-developed and developing countries.

In this case, we can state another economic aberration: inflation still remains extremely low and continues to fall in well-developed countries, despite all the unconventional measures of central banks and their growing balances.

In our opinion, special attention, bearing in mind the issues raised, should be given to the study of exactly the transmission mechanism of promotional monetary policy, which allows taking into account the interaction of all socio-economic processes, while harmonizing the interests of all groups of participants and balancing resources of all kinds.

\section{Theoretical background of the research}

The results of the study of the transmission mechanism and its influence on the strategic development of the state are presented in works of many scientists and experts including: J. M. Keynes, J. Tobin, F. Mishkin, B. Bernanke, J. Taylor, M. Gertler, S. Cecchetti, M. Friedman, J. Stiglitz, and others.
Studies show that the most significant results based on considerable theoretical and practical research were achieved by industrialized countries. At the same time, it should be noted that despite such significant developments in the field of studying the mechanism of monetary transmission, the views on its impact on the development of economy differ significantly, which is explained by individual conditions and goals of the functioning of a state.

For the first time, the transmission mechanism and its impact on the economy are mentioned in the Keynesian analysis. J. M. Keynes called the transmission (transfer) mechanism a system of variables, through which the supply of money affects economic activity. He believed that monetary regulation and changes in the volume of money supply have an impact on reproduction only by influencing the investment process and only if it is able to change the psychological situation in the money market by lowering the rate of interest. Keynes published his work on the analysis of economic activity in 1936, but his views' peak popularity among economists came in the 1950s and early 1960s when most economists adopted his system of evidence (Semiturkin, 2013). Over time, representatives of the monetarist school of economic thought supplemented this theory in a number of aspects.

Now, when it is especially important to continue research, these issues are dealt with by the Central Banks of various countries of the world, as well as by supranational organizations. Economic theory and world practice have developed certain approaches to understanding the operation of the mechanism presented, which allows central banks to use them when developing and implementing monetary policy. Taking into account theoretical and empirical approaches to the study of this issue, specialists significantly expand the concept of the transmission mechanism and present it as a dynamic phenomenon characterized by constant changes, endogenous with respect to the characteristics of the economic system. In fact, the study of the effect of the transmission mechanism is very complex, but the socio-economic processes taking place in a state largely depend on its effectiveness.

As for developing countries, their experience and achievements are not so significant, since in most cases, they are only approaching the process of developing the most acceptable model of the transmission mechanism, one of the main goals of which is to ensure the efficiency of transformation processes. It should be noted that, despite so much attention from developing countries to the study of the transmission mechanism, the ability to implement already proven practices is offset by a number of factors. The main ones are the following: underdevelopment of market institutions, intervention by the state or a number of states in economic processes, monopolization of the economy, a significant proportion of the shadow economy, high 
inflation, dollarization, and a number of other aspects. All this leads to the fact that the measures developed do not correspond to the real state of affairs, feedback is lost between the participants in the process; the mechanism of the transfer mechanism, the quantity and quality of the statistical data are distorted, which, in turn, seriously complicates the problem of an adequate assessment of its impact. Thus, when studying the transmission mechanism in developing countries, it is necessary to take into account a huge number of exogenous and endogenous factors, as well as a constant change in the economic behaviour of the subjects, the formation and development of the institutional and technological structure. These aspects have a significant impact on the structure of the transmission mechanism and, as a consequence, on the effectiveness of monetary policy.

Within this context, at the first stages of the study of the mechanism presented, the process of analysing its structure, namely, determining the most important and significant channels for transferring monetary policy impulses to the real economy, taking into account the dominant factors and conditions, is of particular practical value. In addition, an analysis of the existing structure of the transmission mechanism makes it possible to establish the strength and speed of feedback between participants and the degree of influence on the real sector and to formulate appropriate proposals for its adjustment or activation.

\section{Several approaches to defining the structure of the transmission mechanism}

In the conventional form, the structure of the transmission mechanism is represented as a set of channels, which are peculiar links of macroeconomic variables, through which the impulse of change is transmitted (Mishchenko, 2015). The analysis of the existing developments on the structure of the transmission mechanism we conducted allows us to state that there is only a description of the general specification of the aggregate of its channels, without an unequivocal opinion on the significance of each of them, as well as on individual aspects of their functioning. It should be noted that views on directions of the transmission influence of monetary policy differ even in countries with a well-developed market economy, despite the length of theoretical and empirical research. At the same time, the modern basis for the study of the transmission mechanism very successfully operates with different views on defining its nature and structure and, despite the difference in approaches, in the applied aspect, they complement each other very harmoniously. At the heart of their differences, there are such fundamental questions as: by what means does monetary policy influence the behaviour of the subjects of the real sector and by what channels do its impulses reach the microlevel.
According to the "moneyview", centralbanks influence the short-term interest rate in order to transfer the impulse to the exchange rate and the long-term interest rate. Their correction leads to a change in the costs of attracting capital, in the ratio of internal and attracted funds, in the volume of investment in production. However, taking into account modern developments in this area, it should be noted that international studies have revealed the low elasticity of short-term interest rates to the costs of raising capital (Semiturkin, 2013).

The main role in the "money view" is given to the demand for investment from the private sector, as a result of which the weaknesses of the financial sector and externalities fall out of the sphere of attention. Supporters of the "money view" stand for models with a minimal number of equations, the main variable of which is represented by monetary aggregates and, as a rule, this theory is used when targeting such ones. The "money view" is also called "traditional" because its postulates are more characteristic of Keynesianism. Moreover, it examines the influence of monetary policy only through the lens of the financial sphere, which greatly narrows down and simplifies its perception. Nevertheless, this approach has its own application potential since it is completely based, as it has already been mentioned above, on traditional macroeconomic models and has a full structural theoretical justification, which is very convenient to use in econometric modelling.

The processes of the influence of monetary policy on aggregate demand and on the development of production are reflected to the fullest extent possible in the "lending view" of the transmission mechanism.

As for the "lending view", its theory is based on the microeconomic models of the neo-Keynesian school and focuses on the fact that the imperfection of the financial market prevents the effective functioning of the financial sector. On the one hand, this leads to limitations of cross-sectoral capital flows, on the other one, to a rise in the cost of credit, that is, to the appearance of a premium for external financing, which is paid by enterprises in the real sector in addition to the initial interest rate. The key point of the "lending view" is that the central bank influences not only interest rates but also the volume and cost of the loan (the amount of the premium). The influence is exercised through a change in the welfare of enterprises, which acts as loan support. The relationship between monetary policy and premium derives from the characteristics of the functioning of the credit market. This feature can be represented in the form of a relationship between the welfare of an enterprise and its creditworthiness: the lower the welfare of enterprises, the less creditworthy they are, that is, the higher the premium for them and the lower the possibility of new borrowings. This effect of the influence of monetary policy on the economy is called a "financial accelerator". It is worth noting that the 
"lending view" is most applicable for economies with a well-developed banking system and a high proportion of loans in financing the real sector. Moreover, the practical importance of this approach is expressed in determining the special role of information asymmetry in determining the amount of the premium for external financing; it divides the behaviour of large and small companies. The "lending view" has considerable analytical potential in determining the viability of a financial institution, which makes it possible to apply it in microeconomic analysis of the selective influence of monetary policy on individual financial institutions.

Relatively recently, in the 2000s, a third view the "supplyview" - emerged. The basis of the "supplyview" is the supply of production factors. After the formation of a monetary impulse, it is production companies that are the first to react, correcting the needs exactly in the factors of production. Thus, restrictive monetary policy lowers the demand for labour, capital and thus leads to a negative production shock. The "supply view" makes it possible to expand the explanation of the work of the transmission mechanism since it views the economy not only from the side of aggregate demand but also from the supply side. This approach has gained special practical recognition due to the fact that it allows studying transformations in the real sector of the economy, to which theory traditionally attributes stationary behaviour in the short term (Moiseev, 2013).

Theoretical and practical analysis of these approaches testifies to the absence of an agreed opinion on the structure of the transmission mechanism. The main reason for the discrepancy in this area lies in the field of the transfer of and control over impulses generated by monetary policy - it creates an initial impulse that is transmitted through the transmission mechanism, without further control over it. In view of the research conditions introduced above, in the process of analysing and evaluating the transmission mechanism channels, particular attention is paid exactly to the channels through which monetary policy maximally impacts the real economy. If we consider this process from a pragmatic point of view, its results should reflect the channel's functionality in achieving the goal set (investment activation, output growth, exchange rate stability, inflation targeting, multi-targeting, etc.), as well as further features and prospects for operation.

Thus, the study of the structure of the transmission mechanism must begin with a review of the stages of development ofimpulses transmitted by monetarypolicy to the real economy. Initially, central bank instruments have an impact on the exchange rate, interest rates, asset prices, and lending terms. At the second stage, there are changes in the nominal expenditures of enterprises and households associated with the correction of prices for financial assets, which in turn leads to a change in the structure of the balance of borrowers, the volume of savings, loans, and investments. The second stage of the correction of market interest rates begins. The third stage is the result of the combined effect of the first two ones and is characterized by the transition to a new economic equilibrium through macroeconomic adaptation, which entails a revision of prices and wages. Differences between the channels of money transmission are observed in the first two stages. These differences are based on the nature of the relationship between participants in economic processes - the presence of violations or lack of communication in any part of the transmission mechanism can reduce or even neutralize the results of monetary policy (Tuleuov, 2014). As for the channels, through which the monetary impulse of the changes passes, such channels as the interest channel, the foreign exchange channel, the credit channel, the asset price channel, the expectations channel, the monetarist channel, etc., are traditionally singled out. However, in order to obtain more accurate research results, a more rigorous and clear classification of the transmission channels is needed.

\section{Classification of channels of monetary transmission}

For effective implementation of promotional monetary policy, a clear understanding of its structure and features of the functionality of the channels declared in the structure is necessary.

The approaches to defining the nature and structure of the transmission mechanism considered above demonstrate that the basis for the theories that define the principles of the transmission mechanism operation is formed by the conditions, under which the market operates (perfect/imperfect ones); within this context, traditional and non-traditional channels of the transmission mechanism (Sinelnikova-Muryleva, 2017) are singled out. Traditional channels operate in the absence of market frictions, aberrations, and asymmetries; the functionalities of these channels are described within the framework of traditional models of the macroeconomic theory.

Imperfect conditions of the functioning of the market are reflected in the functionality of non-traditional (banking) channels, with an emphasis on studying the behaviour of credit institutions. The study of these channels, with consideration for the chosen topics, has a greater practical potential for application since they function under imperfect market conditions, in the presence of information asymmetry in the borrowed funds market, behavioural aberrations of economic agents, which, in principle, characterize modern market conditions. Frictions of the financial market do not allow talking about equality in the cost and availability of domestic and external sources of financing for various economic agents.

In general terms, the classification of the transmission mechanism channels is shown in Figure 1. 


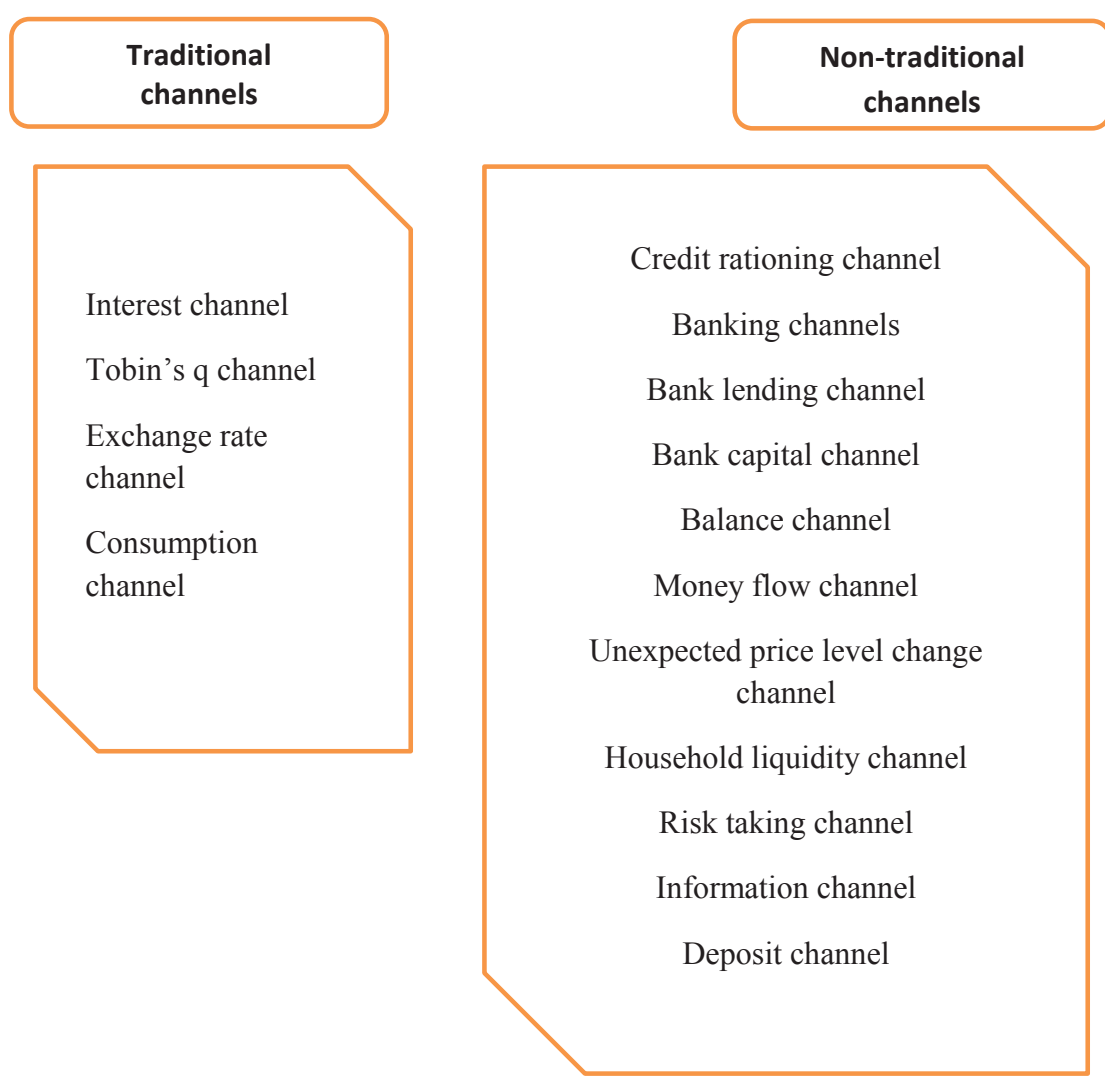

Figure 1. Classification of channels of monetary transmission

In the modern world, many experts are sceptical about studying the neoclassical transmission channels; their arguments are reduced to operating with the fact that the conditions in which they manifest their functionality, by and large, represent a theoretical construction. However, in our opinion, the results of these fundamental developments should be used to solve specific problems. With the help of the ideas outlined in this approach, we can assess the "degree of market perfection", identify factors of influence on the behaviour of economic entities, and adjust monetary activities.

The functionality of these channels, in general, is reflected in the "money view" of the structure and essence of the transmission mechanism.

Interest channel. The functionality of the interest channel is as follows: promotional monetary policyleads to a decrease in nominal interest rates, which reduces the level of real interest rates, which, accordingly, reduces the cost of capital, which leads to increased investment and further to output growth. The degree of the impact of monetary policy on the real economy through the direct interest rate channel depends on the horizon of the effect of interest rates on the costs of economic agents, which is why the focus in this channel is on the relationship between real long-term interest rates and economic agent costs since it is long-term interest rates that reflect the cost of new investment projects. As a consequence, decisions of economic agents on making investments when changes in interest rates take place are decisions made on the basis of analysis of some long-term prospects.

The ambiguity of judgments about the functionality of this channel led to the study of channels that expand the scope of its influence on the choice and behaviour of economic entities. Traditionally, they include: Tobin's q channel, the exchange rate channel, and the consumption channel. Let us consider the features of the functionality of each of the presented channels.

Tobin's q channel. Nobel laureate economist James Tobin suggested that companies make investment decisions based on the following ratio, now called the "Tobin's $\mathrm{q}$ ratio" (Tobin, 1969). Tobin's indicator relates the market value of a company (measured by the market price of its shares) to the replacement value of its assets (1):

$$
q=\frac{P}{C}
$$

where: $\boldsymbol{P}$ is the value of capital assets that is formed in the securities market; $\boldsymbol{C}$ is the replacement value of the company's assets equal to the amount of expenses necessary to acquire the company's assets at current prices.

Tobin believed that the amount of net investment should depend on whether $\mathrm{q}$ is more or less than one. 
If $\mathrm{q}$ is greater than one, then the securities market values the registered capital at an amount greater than the cost of its replacement. In this case, enterprises can make new investments at the expense of fewer shares that have a high price in the market.

The Tobin's q model makes it possible to describe the following transmission mechanism: the result of the promotional monetary policy is an increase in the amount of money in economic agents, as a result of which they are inclined to invest these funds, including in the stock market. The growing interest in investing in the stock market leads to an increase in the value of shares, which, accordingly, increases the $\mathrm{q}$ indicator. As a consequence, the cost of new equipment becomes inexpensive relative to the market value of a company, which stimulates companies to make investments and, ultimately, increases output.

Exchange rate channel (international trade channel). This channel is one of the key channels of the transmission mechanism. In its functionality, parity of interest rates is also included. With lowering the interest rate, the value of domestic assets of a state is also reduced. In comparison with foreign assets, they lose their investment attractiveness. The change in the vector of interests of economic agents towards foreign assets whose value is expressed in foreign currency devalues the national currency. Positive results of the devaluation of the national currency are represented by an increase in net exports and aggregate demand. A large number of scientific works are devoted to the investigation of the functionality (working capacity) of this channel (Sinelnikova-Muryleva, 2017). Such interest is caused by its immense importance for monetary policy and its effective implementation. Through the exchange rate, formed within the framework of flexible exchange rate formation, this channel is one of the most volatile macroeconomic indicators: it is the first to react to various shocks and economic changes due to the absence of rigidity in the foreign exchange market.

Empirical analysis of the functionality of this channel makes it possible to identify several significant and important points affecting its effectiveness: the sensitivity of the exchange rate to changes in interest rates, as well as the degree of openness of the economy, since the more open the economy, the greater the importance of the exchange rate channel. In addition, the growth of globalization and openness of economies is an important factor leading to the growth of the importance of the role of the exchange rate channel in monetary transmission.

Consumption channel. The functionality of this channel allows displaying the actions of monetary transmission in the field of consumption by changing the relative prices in the economy. In addition, its functionality allows identifying several effects, the consideration of which will allow clearer determining the environment of its influence: the substitution effect and the effect of wealth (the income effect).
The direction of the substitution effect is always "negative", i.e. in response to the growth (relative) of the price of a product the consumer reduces its consumption. The direction of the effect of wealth in the general case is not determined and proceeds from an agent's preferences, as well as from the condition of the initial (original) possession of wealth. The mechanism of the effect of wealth lies in the fact that promotional monetary policy will increase agents' demand for assets in view of the fact that agents will have more money in their hands and they will strive to spend them, including in the markets of various assets, which leads to an increase in their cost. The consequence of the increase in the cost of assets will be an increase in the financial wealth of a household, which will increase the amount of resources available for consumption. This will stimulate the consumption of economic agents and, as a result, increase aggregate demand. However, when studying the influence of this effect, it is worthwhile to clearly understand that the direction of its influence will depend on whether an agent is a lender or a borrower, as a change in prices redistributes wealth between them. A fall in the price level increases the real value of the debt of a borrower, as a result of which the creditor becomes enriched.

The study of the functionality of the non-traditional channels of the transmission mechanism, as already mentioned above, is carried out under imperfect conditions of the financial market, namely in all kinds of credit markets, as a result of which very often these channels are called credit channels. These channels make it possible to explain the compositional effects of monetary policy to a greater extent, as they reflect the increased role of the credit market in the development of the economy and, as a consequence, the transition of monetary authorities to the use of measures of unconventional monetary policy. In general, the functionality of non-traditional channels can be represented as the process of redistribution of limited borrowed funds for both banks and corporations.

Credit Rationing Channel. Credit rationing is observed in cases where creditors do not issue loans to borrowers willing to pay interest at the rate set, even if they all agree to deposit the relevant funds as collateral and meet all other requirements for their solvency. Lenders are confident that a high-interest rate will lead to more rapid growth in bad debts than a low-interest rate. Therefore, with the implementation of promotional monetary policy, a low-interest rate makes loans more affordable and raises demand from less risk-prone borrowers. The result will be an increase in the number of solvent borrowers, which weakens the problems of creditors relating to adverse selection. All this is reflected in the rise in lending levels, which stimulates an increase in investment and, further, in output.

Banking channels. This type of transmission mechanism channels is considered by experts as mechanisms, through which the impact of interest rates on the market 
is increased. In addition, the existence of these channels is explained by the fact that economic agents do not always have access to ways of financing investments other than bank loans. Banking channels are divided into the bank lending channel and the bank capital channel.

The bank lending channel arises as a result of the presence of information asymmetry in the financial market and, directly, banks play a key role in its resolution. Information asymmetry in the financial market leads to the fact that, for most of the economic agents, bank lending is the only available source of borrowed resources. This significantly limits the freedom of choice and the interchangeability of resources. Empirical analysis has shown that the bank lending channel has the greatest impact on small businesses and households that have no access to alternative sources of financing, unlike large enterprises.

The functionality of this channel is that promotional monetary policy increasing reserves and bank deposits, accordingly, increases the volume of a bank's credit resources, which, given the situation, allows lending to a large number of economic agents; as a result, the growth of investment activity and of aggregate demand takes place. It should be noted that the bank lending channel is connected with the study of the influence of monetary policy on the volume of lending by various deposit institutions.

A critical question posed by experts when examining the functionality of this channel is whether monetary policy really has such a significant impact on the supply and price of bank resources (Bernanke, Gertler, 1995). With a restraining monetary policy, as a result of open market operations conducted by the central bank, the volume of bank reserves, including deposits, is significantly reduced, which leads to a reduction in lending volumes. Taking into account this situation, the process of adaptation to new conditions, which directly depends on the rate of substitution of deposits by alternative sources, becomes very important for banks. This situation took place in the United States as a result of "Regulation Q"; it was characterized by higher reserve requirements and the presence of less developed and liquid markets for banking obligations. However, experts note a decrease in the functionality of this channel due to the simplification or cancellation of a number of institutional constraints, as well as to the rapid spread of financial innovations.

Bank capital channel. The ideological component of the functionality of this channel is based on the fact that the state of the balance sheet of financial intermediaries affects their credit potential. Promotional monetary policy can lead to an increase in asset prices, therefore, external financing for banks becomes cheaper, the risk of losses in the structure of the loan portfolio is reduced, and its quality increases. It is quite logical to revise the active part of the bank balance in the direction of increase. In addition, low-interest rates increase net interest margins and lead to higher profits for banks, eventually improving their balances due to the possibility of reinvesting profits and increasing the return on assets (Bernanke, 1988). This will have a positive effect on the investment climate in the state and will help increase output.

Balance channel. Numerous scientific studies conducted within the framework of studying the functionality of the balance channel demonstrate its significance for the implementation of promotional monetary measures for the development of the state economy (Bernanke, Gertler, 1989). The main emphasis in the studies is put on the study of the potential impact of changes in monetary policy on the state of an enterprise's balance sheet and its main indicators. It should be emphasized that, as in the case of the bank lending channel, consideration of its functionality takes place in the presence of information asymmetry in financial markets. At the same time, despite the similarity in functionality with the bank capital channel, there is a difference between them, which consists in the fact that, in the first case, balances of financial intermediaries (creditors) are analysed, and in the second one, balances of economic agents (enterprises and households). The mechanism of action of this channel is that during the implementation of incentive monetary measures, the value of the assets of an enterprise increases, which is reflected in the increase in its collateral value and, accordingly, its creditworthiness; at the same time, the share of agents in the authorized capital of the enterprise also increases, which focuses their attention on the development of the enterprise and leads to a drop in demand for risky projects. The share of noncreditworthy enterprises decreases, the probability of non-repayment of loans decreases, information asymmetry decreases, the problem of unfair behaviour is partially levelled off, which leads to increased lending.

The study of the influence of the state of a borrower's balances on his business activity has developed in the theory of "financial accelerator" (Bernanke, Gertler, Gilchrist, 1999). The essence of this theory is that the primary shock that led to a change in a borrower's balance sheet, as a result of the effect of "financial accelerator", multiplies many times, affecting his business cycle.

Very often, in the literature, one can find another channel that complements the analysed one, namely, the money flow channel (Sinelnikova-Muryleva, 2017). The functionality of the channel with promotional monetary policy leads to a reduction in interest payments on the loan of an enterprise, which increases its money flow, improves its balance and liquidity, as well as the creditors' confidence in paying the loan.

Unexpected price level change channel. The functionality of this channel leads to a decrease in the value of a company's debt obligations in real terms as a result of unexpected growth in stock prices. Thus, reducing the debt burden leads to an increase in the company's real value. 
Household liquidity channel. The functionality of the channel in question is that, as a result of promotional monetary policy, the prices and the value of an enterprise increase, which in turn influences its investment preferences toward investing in illiquid assets; accordingly, the demand for durable goods and real estate increases, which increases output.

Risk-taking channel. It should be noted that this channel has received its understanding and development relatively recently. Under conditions when interest rates are close to zero, this affects the reduction of bank profits, which leads to the fact that banks are more inclined to invest in risky projects (Borio, 2012). It is noted that, in addition to the above, low-interest rates increase the value of assets and collateral, which is reflected in an increase in the bank balance and in the improvement of the financial condition of a borrower, which leads to a reassessment of bank risks.

Deposit channel. Just like the risk-taking channel, it is quite new. Its functionality is based on such assumptions as: banks have market power, which is to regulate the liquidity of economic agents; in addition, the value of deposits for agents is determined by their liquidity and security (Drechsler, 2014). An example of the functionality of this channel can be the United States, where the growth of the rate for federal funds led to an outflow of deposits due to a disproportionate change in spreads for different types of deposits. Analysis of empirical data showed that the interest in highly liquid demand deposits increased more than the interest in urgent deposits. The result is capital flow from deposits into cash, and then the latter is invested in less liquid assets, and not in deposits, but rather in shares or bonds. In a natural way, this reduces the credit resources of banks and the volume of investments and output decreases.

Information channel. Recently, special attention has been paid to studying the information channel of the transmission mechanism; this is due to the fact that the importance of certain channels due to the development of financial markets and the weakening of market frictions is falling. The functionality of this channel is expressed in maintaining by the central bank a certain level of expectations of economic agents through information interventions. Supporting a high level of inflationary expectations, the monetary authorities also affect the reduction in the real interest rate, which is well explained by the Fisher equation and is considered as the difference between the nominal rate and the expected inflation and leads to an increase in investment activity.

\section{Modern modifications of promotional monetary policy}

Analysis of modern approaches to the study of monetary policy demonstrates that the functionalities of many channels lose their relevance and significance under modern conditions characterized by economic instability, the unpredictability of emergence of crisis situations, and the presence of contradictory trends. Already now, the world economy is characterized as the "new abnormal" in terms of production volumes, economic policy, inflation, the behaviour of financial markets, and the dynamics of prices for key assets (Rubini, 2016).

As a result, special attention is paid to the effective implementation of non-traditional monetary measures that provide an opportunity to take a fresh look at the already established (traditional) and especially to highlight the functionalities of non-traditional channels. Non-traditional monetary measures include: zero interest rates policy (ZIRP), quantitative easing (QE), credit easing (CE), central bank statements about future intentions/signalling measures (FG - forward guidance), negative deposit rates (NDR), unsterilized foreign exchange intervention (UFXInt). Each of the presented non-traditional measures represents a derivative of innovative approaches in the financial field and of the functionality of non-traditional monetary channels.

Zero interest rates policy is a direct outcome of promotional monetary policy; it is based on the functionality of the interest channel and is used during periods of economic downturn. Central banks minimize the interest rate, which makes the monetary resources as accessible to all groups of economic agents as possible.

The program of quantitative easing is used in conditions of zero/near-zero short-term interest rates when the alternative costs of keeping money are also close to zero; there is the so-called "liquidity trap" that, with increasing money supply, absorbs excess money supply through increased money demand. Investment activity is falling, which leads to lower output and neutralizes, ultimately, promotional monetary actions. To overcome this problem, as it has been mentioned above, the quantitative easing program is used, which is used when the interest rate cannot be pushed any lower. This program operates on the basis of various methods for mitigating national reserve requirements: reducing mandatory reserve requirements, introducing new rules for averaging reserves, expanding the list of allowed exceptions in calculating reserve requirements, etc. As a result, the level of money supply increases, which affects investment and output. A distinctive feature of quantitative easing is that its purpose is not to change the interest rate but to increase the money supply.

As for credit easing, its mechanism of action is that, on the basis of various methods, for example, through lending to financial institutions, through the provision of liquidity to key credit markets or through the acquisition of long-term securities, various financial markets are stimulated. The application of these measures allows central banks to perform the function of the lender of last resort in a new way. 
The effectiveness of the policy of quantitative and qualitative easing can be well traced in the case of well-developed economic countries such as Japan and the United States, the analysis of which makes it possible to identify the necessary condition for effective implementation of those monetary measures, namely, a smooth process of bank lending.

Signalling measures act indirectly through perceptions and expectations of economic agents. The mechanism of the action of signalling measures is essentially based on the immanent results of promotional monetary policy; it is the impact on the level of inflationary expectations on the part of economic entities. In addition, the expectation factors include: expectations from the future policy course, expectations of a relative shortage of various assets and their risks. In addition, it can also be seen in the literature that signalling measures are also called policy commitment or policy announcements (Kavitskaya, 2011).

The policy of negative deposit rates implies an increase in the money supply by additional injection into the economy through a negative interest rate. The mechanism of action of this policy is that an amount less than the loan amount has to be returned, which increases the amount of monetary resources of the bank and, accordingly, of economic agents. In 2008-2016, against the backdrop of the global crisis, the policy of negative interest rates was introduced on a temporary or long-term basis in countries such as Sweden, Japan, Denmark, Italy, Switzerland, and the Netherlands; also, in 2014, negative rates were introduced by the European Central Bank. Supporters of this policy believe that it can facilitate the emergence of utterly debt-ridden Western economies from the crisis.

Unsterilized foreign exchange intervention is one of the types of official currency interventions that result in changes in the monetary base. In the context of promotional monetary policy, the central bank buys foreign currency and sells the national currency, as a result of which there is an increase in international reserves and an increase in the monetary base and, accordingly, an increase in the money supply.

It can be stated that critical changes in the leading countries of the world led to a revision and further modification of promotional monetary policy and, accordingly, of the role of non-traditional channels.

It should be noted that the central banks of not only well-developed but also developing countries had to resort to such measures. However, the scope of application of non-traditional monetary measures in developing countries was much smaller. The sets of instruments used by the central banks of developed and developing countries were also significantly different.

A very important point that demonstrates the need for such a careful study of all approaches to and views of the structure of the transmission mechanism of promotional monetary policy is that there is no single recipe for its application. One cannot just limit oneself to the division of countries in well-developed and developing ones. A certain economic community is present; on the other hand, well-developed countries have a high level of institutional development; their structure of financial markets and their scheme of the interaction of fiscal and monetary policies, their high standard of living etc. are fundamentally different than those of developing countries. And, despite the growing role of economies of developing countries, it is not possible to overcome certain aspects of the ideological component of their development in the near future.

The study of the fundamental bases of the strategic development of developing countries demonstrates either the absence of a systematic approach, or it is considered only at the theoretical level as such, without further implementation in real economic life. As a result, we can observe a number of negative and, what is not unimportant for the implementation of effective monetary measures, destructive consequences; they include, at the methodological level: the absence of a single conceptual apparatus, the absence of a unified system of indicators for assessing effectiveness, the absence/non-use of adequate forecasting techniques, imperfection of methodological tools, insufficient application/non-use of economic-mathematical methods; at the organizational level: the absence of an adequate regulatory framework, nominal and declarative nature of measures, the absence of effective monitoring, control, and coordination mechanisms, lack of accountability, a high degree of bureaucratization, inertia and lack of flexibility, the complexity of the planning procedure, etc. However, with a deeper analysis of the causal relationships, we can state more complex causes of destructive nature, which initially level out practically any actions with regard to the system approach, namely, the absence of the integrated combination of interests of all social and economic spheres: state-business-society. Moreover, the study of each component of the presented triad, in developing economies, in most cases, indicates that they are also in the process of formation - without clear contours, rules, and principles of functioning, since a country that is at the stage of transforming the ideological foundations passes a sufficiently long stage of their formation, which is often expressed in conflicts of interests and the adoption of destructive solutions at all levels.

In fact, this explains the absence or an insignificant number of really adequate, and therefore effective, promotional monetary measures since they are developed taking into account clearly arranged and functioning elements, which, a priori, is not true. To introduce something in order to obtain a maximum effect is possible only if there is a "contact", feedback, and clear rules between the participants in the process.

At the same time, when studying the transmission mechanism in developing countries, it is necessary to 
understand that the influence of destructive factors is strengthened by such aspects as: the formation of the transmission mechanism occurs under the conditions of a continuous change in the economic behaviour of agents, of the formation and development of the technological and institutional structure; the influence of a huge number of exogenous and endogenous factors, for which reason the central bank must take into account the consequences of economic shocks arising independently of its own influence, as well as the impact of technological and structural changes in the transformational economy and changes in the behaviour of economic entities.

Empirical analysis of monetary policy and, accordingly, the transmission mechanism in most developing countries has shown that the most significant channels are the exchange rate channel, the interest channel, and the credit channel. The functionalities of these channels have been discussed above, but their reach is limited by such conditions as: a low level of financial market development, high public sector share, a high degree of dollarization of financial assets, exposure to macroeconomic shocks. The result of the influence of these factors is reflected in the functionality of each of them.

Despite positive consequences of the devaluation of national currency in the form of growth in net exports, this leads to a decrease in net wealth, makes investment less attractive, which affects the amount of financial resources attracted and results in lower investment and output.

As for the interest channel, its impact on the real economy is rather insignificant, primarily due to a low level of the development of the financial market. Also, in economies with high inflationary processes, the effect of this channel is neutralized by the high volatility of inflation.

The range of the functionality of the credit channel is often limited by the functionality of the banking channels (the bank lending channel and the bank capital channel). The functioning of this channel is not efficient enough due to the unfavourable credit climate, high risks, the absence of solvent borrowers and tight price and non-price lending conditions amid a general decline in the profitability and solvency of borrowers.

\section{Conclusion}

The conducted study clearly demonstrates that, in the process of changing financial relations, the significance of the transmission mechanism channels in the process of implementing promotional monetary policy changed, too. At the same time, it is expedient to single out the reasons that lead to a change in the role of some channels of monetary transmission in relation to others.

The first group includes institutional changes in financial markets. We should also note that the structure of financial markets is of key importance from the point of view of the functionality of individual channels of monetary transmission, as well as of the effectiveness of monetary policy in general.

The second group of reasons would include changes in monetary policy modes to achieve the corresponding goal. In particular, a transition from one mode of monetary policy to another is usually associated with the fact that the central bank starts using different instruments of monetary policy. The most significant factor in the third group is the emergence of the socalled expectations channel, which plays an increasing role in terms of monetary transmission, reducing the importance of traditional channels.

Modern research and developments are not limited to the above structure of the transmission mechanism channels. Moreover, their list is constantly replenished, which is indicative of the existence of transformational processes affecting the financial sector. The approaches to the structure of the transmission mechanism and the functionality of its channels, determined in this article, make it possible to assess the effectiveness of implementing monetary policy.

Further research will be aimed at determining the impact of monetary policy modes used on the structure of monetary transmission.

\section{References:}

Semiturkin, O. N. (2013). Kharakteristika transmissionnogo mehanizma denezhno-kreditnoy politiki v razlichnyh ekonomicheskih shkolah [Characteristics of transmission mechanism of money and credit policies in different economic schools]. Vestnik Omskogo universiteta, 3, 228-233. (in Russian)

Mishchenko, V. I., Mishchenko, S. V. (2015). Udoskonalenniia dii kanaliv transmissiinogo mehanizmu hroshovo-kreditnoi polityky v Ukraini v umovah perekhodu do targetuvaniia infliatsii [Improving of the acting of the channels of transmission mechanism of money and credit policies in Ukraine in conditions of transition to inflational targeting]. Retrieved from: http://www.irbisnbuv.gov.ua/cgibin/irbis_nbuv/cgiirbis_64.exe ?I21DBN=LINK\&P21DBN=UJRN\&Z2 1ID =\&S21REF $=10 \& S 21 \mathrm{CNR}=20 \& S 21 \mathrm{STN}=1 \& S 21 \mathrm{FMT}=\mathrm{ASP}$ meta\&C21COM=S\&2_S21P03=FILA=\&2_S21STR=ape_2015_1_52 (in Ukrainian)

Moiseev, S. R. (2013). Transmissionnyi mehanizm denezhno-kreditnoy politiki: osnovnyye polozheniya [Transmission mechanism of money and credit policies: conceptual issues]. Vestnik Pridnestrovskogo respublikanskogo universiteta, 3. (in Russian)

Tuleuov, O. A. (2014). Transmissionnyi mehanizm vozdeistviya netraditsionnogo (nestandartnogo) instrumenta denezhno-kreditnoi politiki - kolichestvennogo smyagcheniya na ekonomicheskuyu aktivnost [Transmission influencing mechanism of non-traditional (substandard) instrument of money and credit policies]. Retrieved from: https://cipe.kz/ $\mathrm{ru} /$ articles/macroeconomics.html?id=30 (in Russian) 
Sinelnikova-Muryleva, E. V. (2017). Analiz transmissionnyh mehanizmov denezhno-kreditnoy politiki banka Rosii $\mathrm{v}$ usloviyah perehoda k infliatsionnomu targetirovaniyu [Analysis of transmission mechanism of money and credit policies of the Bank of Russia in conditions of transition to inflational targeting]. Moskow. (in Russian)

Tobin, J. A. (1969). General equilibrium approach to monetary theory // Money CreditBank, 1(1), 15-29.

Bernanke, B. S., Gertler, M. (1995). Inside the Black Box: The Credit Channel of Monetary Policy. The Journal of Economic Perspectives, 9(4), 27-48.

Bernanke, B. S. (1988). Credit, Money, and Aggregate Demand. American Economic Review, 78(2), 435-439.

Bernanke, B., Gertler, M. (1989). Agency costs, net worth, and business fluctuations. American Economic Review.

Bernanke, B. S., Gertler, M., Gilchrist, S. (1999). The financial accelerator in a quantitative business cycle framework. Handbook of macroeconomics, 1, 1341-1393.

Borio, C., Zhu, H. (2012) Capital regulation, risk-taking and monetary policy: a missing link in the transmission mechanism? Journal of Financial Stability, 8(4), 236-251.

Drechsler, I., Savov, A., Schnabl, P. (2014).The deposits channel of monetary policy. SSRN.

Rubini, N. (2016). 'Novaya nenormalnost': chem bolna globalnaya ekonomika [New abnormality: what illness has the global economics?]. Retrieved from: https://www.rbc.ru/opinions/ economics/05/02/2016/56b444899a794749fb9b8f61 (in Russian)

Kavitskaya, I. L. (2011). Finansovyii krizis i politika Tsentralnogo banka [Financial crisis and Central Bank policy]. Journal of Institutional Studies, 3(4), 27-33. (in Russian) 